\title{
Diel, seasonal and ontogenetic variations in the vertical distributions of four marine copepods
}

\author{
T. Falkenhaug ${ }^{1, *}$, K. S. Tande ${ }^{1}$, T. Semenova ${ }^{2}$ \\ ${ }^{1}$ Norwegian College of Fishery Science, University of Tromsø, N-9037 Tromsø, Norway \\ ${ }^{2}$ Institute of Oceanology, Russian Academy of Sciences, Krasikova St. 23, Moscow 117218, Russia
}

\begin{abstract}
Diel and seasonal variations in the vertical distributions of Calanus finmarchicus, Metridia longa, M. lucens and Chiridius armatus in Malangen, northern Norway, were determined from February until December 1992. The vertical behaviour differed among the species and among the different stages of a single species. The vertical distribution of $C$. finmarchicus was dominated by seasonal rather than diel vertical migration, and this species was found in surface waters during the spring phytoplankton bloom (March to May), and at the bottom of the fjord in the fall and winter. Metridia spp. were generally consistent diel vertical migrators. However, $M$. longa usually stayed deeper and had a larger migration amplitude than $M$. lucens. $M$. longa was more deeply distributed in the winter than during the summer, while $M$. lucens showed no such seasonal trend. The vertical behaviour of $C$. armatus was related to the seasonal change in day length, and diel vertical migration was strong in periods of large day/night contrast (spring and autumn), but ceased during the periods of midnight sun and winter darkness. During the summer C. armatus stayed deep both day and night. Diel vertical behaviour in young stages of all 4 species was weak or undetectable by the sampling method used. Younger stages of C. finmarchicus and Metridia spp. remained higher in the water column, while the opposite was observed in C. armatus. While seasonal variations in vertical behaviour are related to variations in food and light conditions, inter- and intraspecific differences may be due to life history, diet and susceptibility to predation.
\end{abstract}

KEY WORDS: Zooplankton - Copepods - Vertical distribution · Vertical migration Fjords - Northern Norway

\section{INTRODUCTION}

The water column of the ocean provides a diverse habitat gradient in which light, temperature, food and predation risk all change with depth (e.g. Banse 1964, Mullin 1979). Thus, the vertical distribution of zooplankton may be regarded as a process of habitat selection, in which the organism must trade off various selective forces (Giske et al. 1990): (1) visual predation from fish, (2) non-visual predation from carnivorous zooplankton, (3) the vertical distribution of food, and (4) the cost of migration. The outcome of this trade-off is influenced by environmental factors such as light (Russel 1927, Cushing 1951, Ringelberg 1991), abundance of food (Pearre 1973, Huntley \& Brooks 1982), predator abundance (Bollens \& Frost 1989, Lampert

•E-mail: tonef@nfh.uit.no
1989, Ohman 1990) and hydrography (Banse 1964, Pearre 1979). Furthermore, inter-and intraspecific differences in the response to these environmental factors are due to differences in fecundity (Gabriel \& Thomas 1988), size (Landry 1978, Sullivan 1980, Yen 1985), behaviour (Gerritsen \& Strickler 1977, Zaret 1980, Greene 1988, Ramcharan \& Sprules 1991) and pigmentation (Kerfoot 1985). Temporal variations in environmental factors combined with species-specific responses to these changes enhance diel and seasonal variations in the vertical distribution of zooplankton organisms. The vertical distribution and migration of zooplankton has been studied since the early years of plankton research (Russel 1927, Cushing 1951, Banse 1964) and the literature on the vertical distributions and migration of copepods is extremely large. However, most studies have been limited seasonally, or focused primarily on the adult females. 
This paper presents monthly data on the vertical distribution of Calanus finmarchicus (Gunnerus), Metridia longa (Lubbock), M. Iucens and Chiridius armatus in a north Norwegian fjord. These species are among the dominant species in the fjords and coastal areas of northern Norway (Falkenhaug et al. 1997) and differ in body size, pigmentation, trophic position and life history. At high latitudes, several environmental factors change dramatically with the season: the day length (sun above horizon) varies from $24 \mathrm{~h}$ in the summer to $0 \mathrm{~h}$ during winter. The length of the primary production period is restricted to a few months in the spring (Eilertsen et al. 1981), and the hydrography in coastal waters undergoes strong seasonal variations. Accordingly, this study covers different seasons, species and developmental stages, providing a wide variety of biotic and abiotic conditions which are expected to affect the vertical distributions of copepods. With predation being invoked as the primary selective force behind diel vertical migration (DVM), the following specific predictions can be made: (1) copepods should have a deeper night-distribution during summer, (2) DVM decreases during periods of small diel changes in light and (3) the intensity of DVM increases with susceptibility to predation.

\section{MATERIALS AND METHODS}

The study was carried out in Malangen $\left(69^{\circ} 30^{\prime} \mathrm{N}\right.$, $18^{\circ} 21^{\prime} E$ ) in the vicinity of Tromsø, northern Norway (Fig. 1). The fjord is separated from the ocean in the north by a $200 \mathrm{~m}$ deep sill, and is divided into 2 basins with maximum depths of 250 and $400 \mathrm{~m}$. Between the 2 basins lies a shallower area with a sill depth of $160 \mathrm{~m}$ The fjord is highly influenced by the coastal waters along the coast, resulting in high temperatures $(6$ to $7^{\circ} \mathrm{C}$ ) and salinities ( 34 to $34.5 \%$ ) in the deeper layers all year (Falkenhaug et al. 1995, 1997). Stratification of the water column during spring and summer is due to freshwater run-off from the river Malselv at the fjord head (Falkenhaug et al. 1995). A more detailed description of the fjord is provided by Falkenhaug et al. (1995). The light climate in the Malangen area changes dramatically during the year (Fig. 2), varying from winter darkness (28 November until 14 January) to midnight sun (19 May until 26 July). Between these periods, the day length changes from 0 to $24 \mathrm{~h}$ in the course of $4 \mathrm{mo}$

Ten cruises were made between February 21 and December 16, 1992, with RV 'Johan Ruud'. Zooplankton sampling was performed during the day $(10: 00$ to $14.00 \mathrm{~h}$ local time) and at night (22:00 to 02:00 $\mathrm{h}$ local time) with a $1 \mathrm{~m}^{2}$ MOCNESS (Wiebe et al. 1985; mesh size $=180 \mu \mathrm{m}$, vertical hauling speed $=0.16 \mathrm{~m} \mathrm{~s}^{-1}$, horizontal speed $=0.6 \mathrm{~m} \mathrm{~s}^{-1}$ ). The following discrete depth strata were sampled: $0-20$, 20-50, 50-100, 100-150, 150-200, $200-250$, and $250-360 \mathrm{~m}$. Hydrographical data were obtained using a Neil Brown CTD profiler and chlorophyll fluorescence was measured with a BackScat Fluorometer Model $1121 \mathrm{MP} / \mathrm{Chl}$ la mounted on a Multiparameter CTD Probe OTS 1500 (ME Meerestechnik-Elektronik GmbH).

Zooplankton samples were split with a Motoda splitter device (Motoda 1959). One half of the sample was preserved in $4 \%$ buffered formalin-seawater solution for identification and enumeration of copepods, while the other half was frozen for later determination of ash free dry weight (AFDW). Data on zooplankton biomass are presented elsewhere (Falkenhaug et al. 1995, Falkenhaug 1996). In the

Fig. 1 Malangen fjord, Norway, with sampling station (8) and $100 \mathrm{~m}$ depth curves 


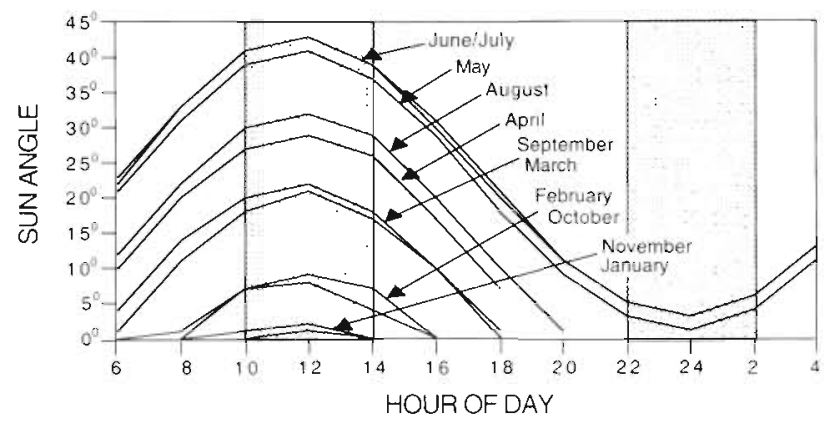

Fig. 2. Elevation of the sun in Tromso on each sampling date. Shaded areas indicate time of sampling

laboratory, mesozooplankton were identified and counted under a binocular microscope on subsamples no less than $1 / 100$ of the total sample.

We used 2 separate indices of DVM as employed by Bollens \& Frost (1989): (1) the weighted mean depth (WMD) was determined for each daytime and nighttime vertical series of samples as

$$
W M D=\left(\sum n_{i} d_{i}\right) / \sum n_{i}
$$

where $n_{j}$ is abundance (no. $\mathrm{m}^{-3}$ ) at depth $d_{j}$, taken to be the midpoint of each stratum. Migration amplitude was defined as the difference between night WMD and day WMD. (2) The strength of migration behaviour, or the proportion of individuals migrating across a given depth during a diel cycle $(V)$, was calculated as the difference between the proportion of the population above a given reference depth at night and the proportion above that same depth during the day. The maximum depth and amplitude of migration varies seasonally. Thus separate reference depths were calculated for each vertical profile as the midpoint between day WMD and night WMD. The $V$ parameter varies between 1 and -1 , with positive values indicating normal DVM and negative values indicating reverse DVM. Each station was sampled only once during the day and once at night. Differences in WMD and the $V$ parameter thus could not be tested statistically, but were assumed to indicate seasonal and ontogenetic variations in the vertical behav- iour of the 4 copepod species studied. In addition, the magnitudes of migrations may have been underestimated, as the samples were not necessarily obtained when the copepod populations were at their minimum or maximum depth distributions. Day and night WMDs should therefore be regarded as approximations.

\section{RESULTS}

\section{Hydrography and fluorescence}

The water column was fairly homogeneous during winter (33 to $34.9 \%$ ), and stratification, due to fresh water run-off, started in April/May and lasted until August/September (Fig. 3). The halocline oscillated around $10 \mathrm{~m}$ during summer, and the greatest stability occurred in June-July. The spring phytoplankton bloom in Malangen in 1992 started in late March/early April, and reached a peak in late April (Fig. 3). After a summer minimum from mid-May until June, a secondary but smaller bloom was found in early July to late August. Chlorophyll values returned to pre-spring bloom levels from mid-October, reaching a minimum in December.
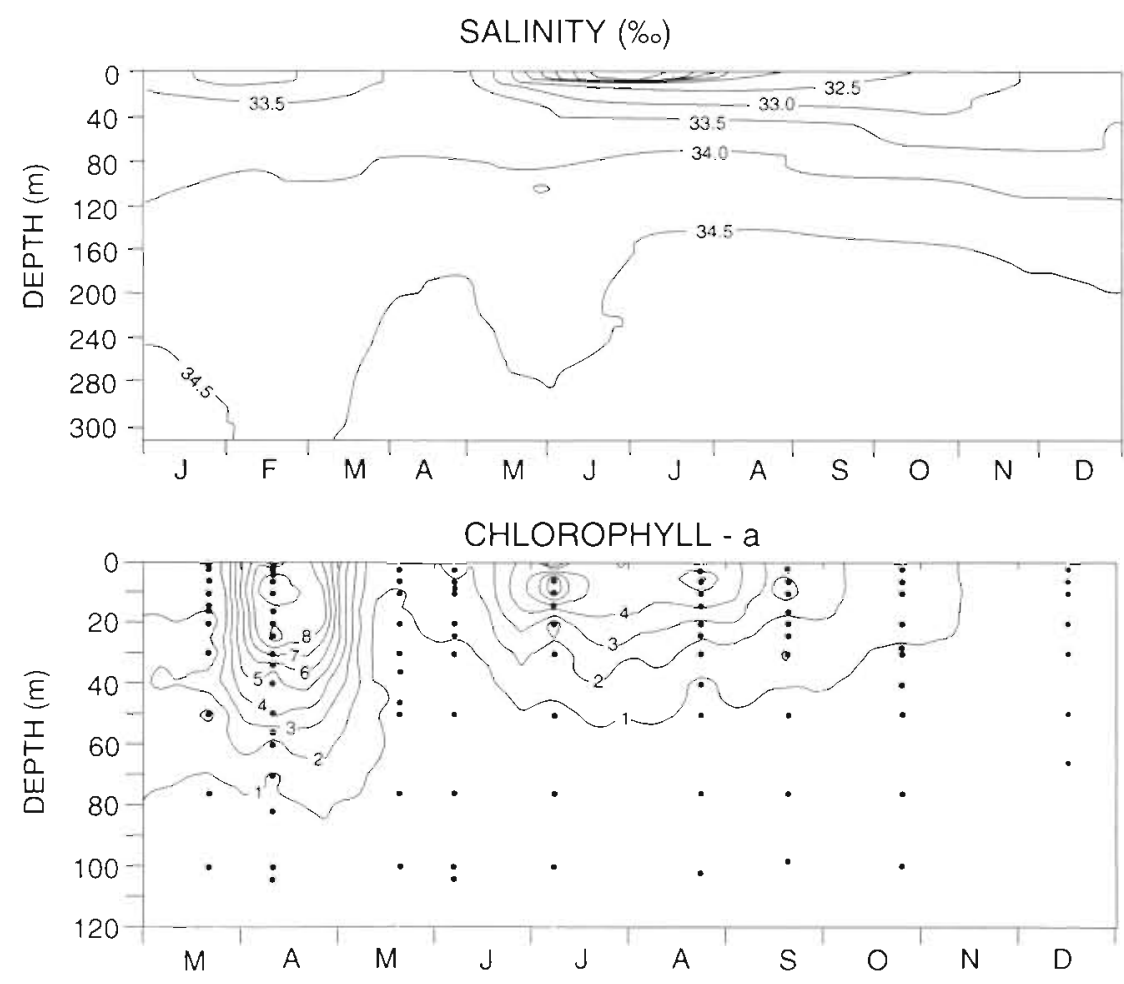

Fig. 3. Salinity and in situ fluorescence ( $\mu \mathrm{g}$ chl a equivalents $\mathrm{l}^{-1}$ ) at sampling station, Malangen, 1992 


\section{Calanus finmarchicus}

Calanus finmarchicus stages $\mathrm{CI}-$ CIII appeared in the top $50 \mathrm{~m}$ in April, with younger stages found slightly higher than the next older stage (Fig. 4a). The depth distribution was usually unimodal, with small migration amplitudes and little indication of any migration on the scales sampled. C. finmarchicus CIV-CV underwent a seasonal migration, in which most of the population stayed below $150 \mathrm{~m}$ during the autumn and winter months (July to February) and returned to the surface in February/March (Fig. 4b). Stages CIVCV were often bimodally distributed with small differences between day and night distributions. However, unimodal distributions for all stages were observed in April (above $250 \mathrm{~m}$ ) and in winter, October/December (below $150 \mathrm{~m}$ ). Stages IV-V were found in the surface during both day and night in the spring (February to May), but tended to avoid the top $20 \mathrm{~m}$ during the day from June onwards. $C$. finmarchicus adult females were found in the upper $100 \mathrm{~m}$, in spring (February to April) and fall (September to December). During the summer (May to August) the copepods were bimodally distributed. C. finmarchicus adult males had a broad vertical distribution in February/March, which gradually became shallower and more concentrated later in the season.

The strength of diel vertical migration $(V)$ in Calanus finmarchicus was usually slight $(<0.5)$ and showed no seasonal trend (Table 1). The highest values were found in stage $\mathrm{CV}$ and adult females. Migration of $C$. finmarchicus males was usually weak, and with low amplitudes. It should be noted that the negative values on some of the dates are due to missing surface data (July) or to low numbers of individuals in the samples.

\section{Metridia spp.}

Metridia spp. stages I-III (Fig. 5a) were found in the top $150 \mathrm{~m}$ during the spring (February/March) and fall (August to December). During the summer, the copepods had a broader vertical distribution and were
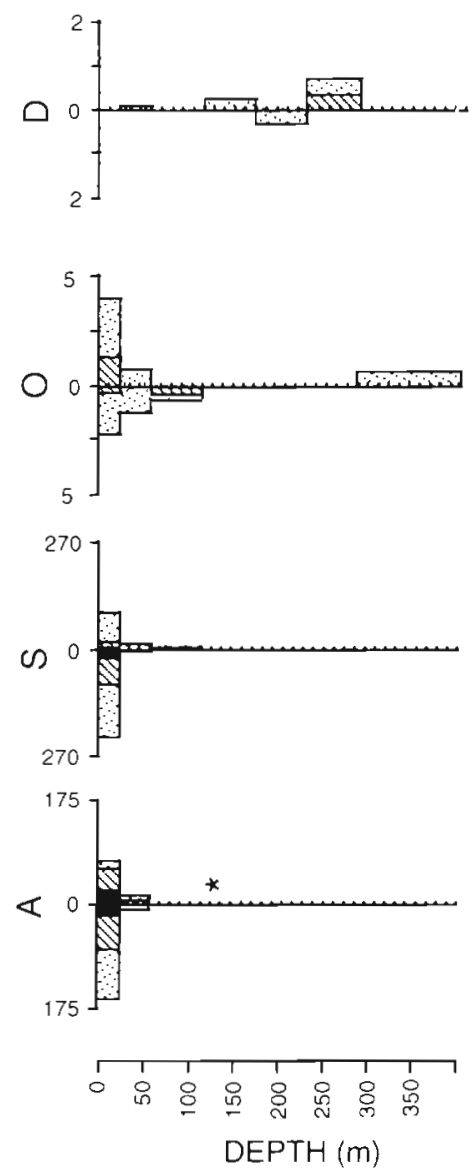

found at depths down to $350 \mathrm{~m}$. Stages I-II avoided the upper $20 \mathrm{~m}$ during the day from March to September but stayed in the surface layer both day and night in February and in October/December. Migration strengths of Metridia spp. stages I-III were usually low and variable, but the higher values were found during summer (April to July; Table 1).

Metridia longa stages IV-V always avoided the top $20 \mathrm{~m}$ during day, and stage $\mathrm{V}$ performed diel vertical migrations during summer (June to September; Fig. 5b). The abundances of CIV-CV were low in February and March, so the migration strength observed on these dates may not be real. High values were found in summer, increasing to 0.6 in September (Table 1). The daytime depth of $\mathrm{CV}$ rose from $100-250 \mathrm{~m}$ in May to $150-250 \mathrm{~m}$ in June/July and $250-350 \mathrm{~m}$ in August. Most of the stage $\mathrm{V}$ population was below $150 \mathrm{~m}$ in October/December. M. longa adult females remained below $150 \mathrm{~m}$ in February/March and October/December (Fig. 5b). Females had a broader distribution in March to June, with a proportion of the population in the surface layers at night. As with $M$. longa stage $V$, especially strong migrations were observed in adult females in September (Fig 5b, 

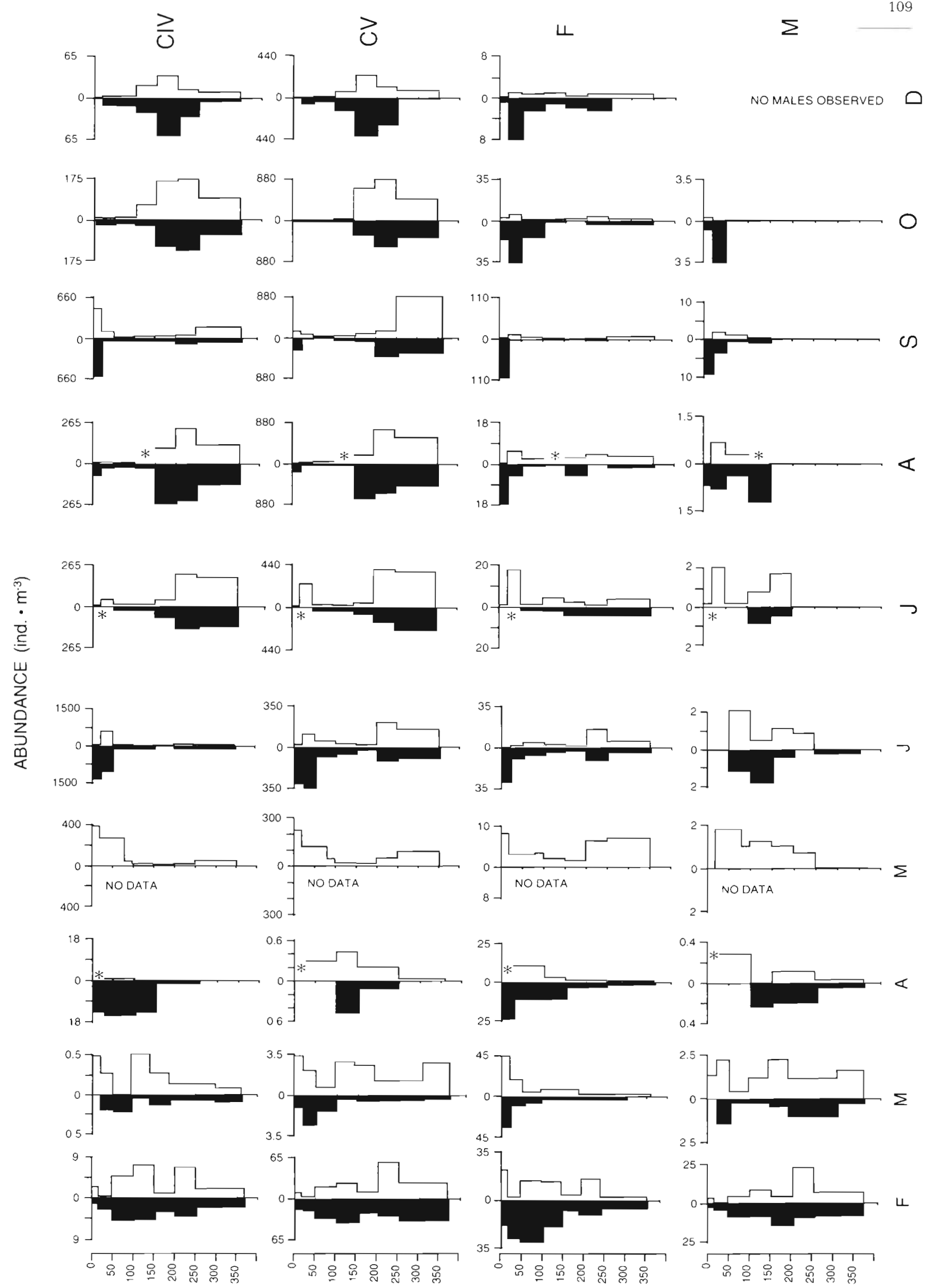
Table 1). At this date, stages IV-VI were almost absent from the daytime samples, but high abundances were found in the upper $20 \mathrm{~m}$ at night. There was no apparent difference in the depth distribution of adult males and adult females

Metridia lucens IV-V were more shallowly distributed than $M$. longa and were found in the top $200 \mathrm{~m}$, except from July when the copepod had a broader vertiCal distribution (Fig. 5c). Stages IV-V always avoided the top $20 \mathrm{~m}$ at day and usually performed diel vertical migration between the surface and 150-200 m. The migration strength of stage $V$ reached its highest values 0.4 to 0.5 ) during the summer (July to September; Table 1). $M$. lucens adult females were distributed in the top $250 \mathrm{~m}$, being more shallow in April than in other months. Adult females always avoided the top $20 \mathrm{~m}$ at day and performed diel vertical migrations on all sampling dates. Migration in $M$, lucens adult females was usually stronger than for stages IV and $V$, and varied between 0.07 and 0.76 . the highest value being obtained in September (Table 1).

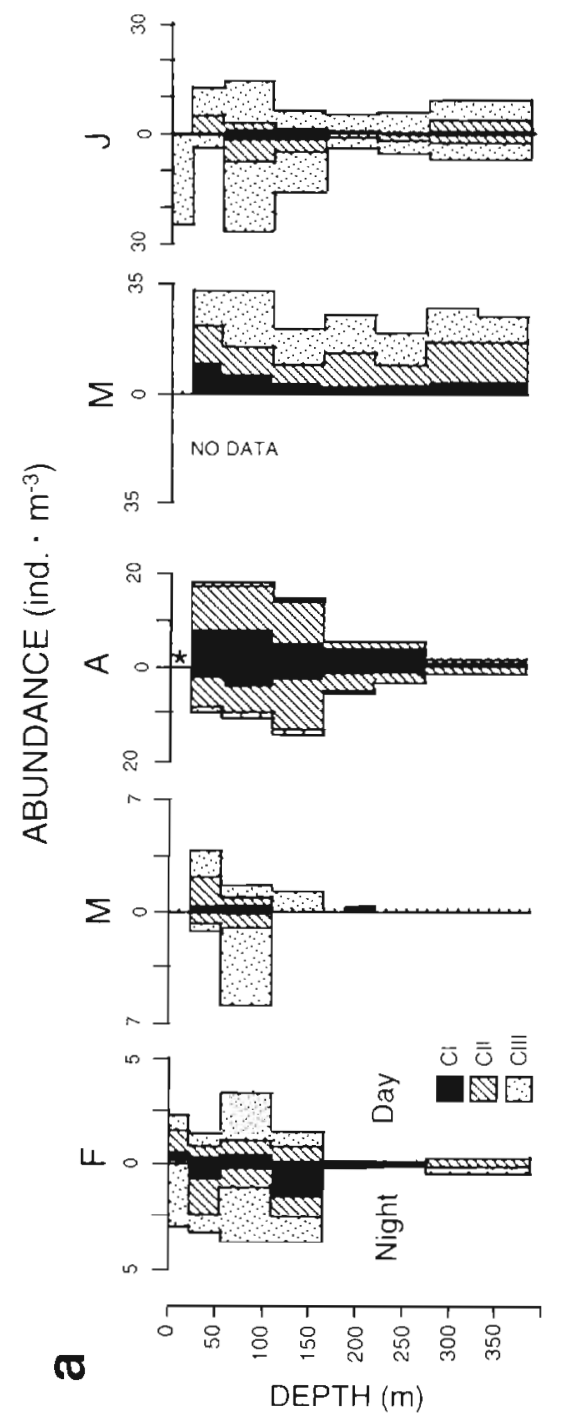

\section{Chiridius armatus}

Chiridius armatus stages I-III avoided the surface $20 \mathrm{~m}$ both day and night, except in February when stages I-III were found in the surface layer at night (Fig. 6a). Migration strengths of stages I-III were variable, but high values were found in February and August to December (Table 1). In summer (June/July) the copepods stayed at greater depths both day and night. Stages I-III usually stayed below $150 \mathrm{~m}$ in the day and below $50 \mathrm{~m}$ during night. Night distributions of stage I were slightly deeper than stage II, which in turn were deeper than stage III. C. armatus stage IV were usually distributed below $150 \mathrm{~m}$ during day and migrated to the surface at night (Fig. 6b). However, the copepod avoided the top $20 \mathrm{~m}$ both day and night in June to August and October. Migration strengths were high all year, with maximum values in February (Table 1). C. armatus stage $V$ and adult females and males performed strong vertical migration in February to April and August to December (Fig. 6b). Migration strengths in these periods were high, reaching values close to 1.0 (Table 1), indicating that $100 \%$ of the population crossed the reference depth during the diel cycle. C. armatus stage $\mathrm{V}$ and adult females were found near the surface $20 \mathrm{~m}$ at night in February and March, but avoided the surface from April to December. During the summer, migration ceased (Table 1) and stages IV-VI stayed below $150 \mathrm{~m}$ both day and night.

\section{Interspecific comparisons}

The vertical behaviour of all stages of the 4 species is illustrated as day and night WMD on all the dates sampled (Figs. 7 \& 8). Younger copepodid stages of Calanus finmarchicus and Metridia spp. were generally 

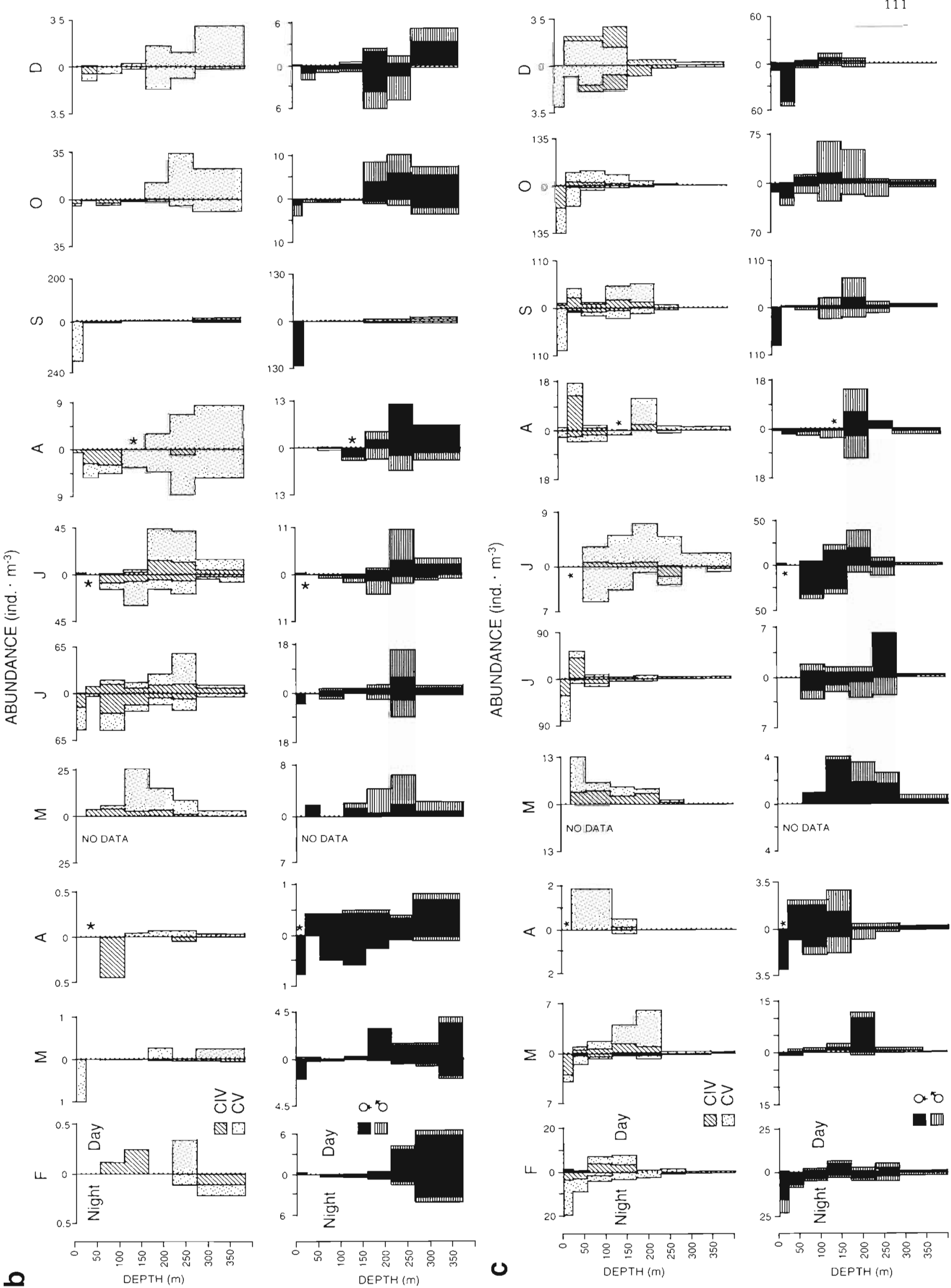
more shallowly distributed than older stages. However, in Chiridius armatus the situation was the opposite: younger stages were found deeper than older stages. There was a trend to older copepodid stages of all 4 species showing larger migration amplitudes than the younger ones. However, males usually had low migration amplitudes, with the exception of C. armatus males, where high migration amplitudes were observed.

Calanus finmarchicus stages I-III were generally more shallowly distributed than Chiridius armatus stages I-III, while Metridia spp. stages I-III were intermediate in depth (Fig. 7). C. finmarchicus stages IV-V had similar WMD to Metridia longa stages IV-V. except from the spring/summer period, when $C$. finmarchicus were shallower. $M$. lucens IV-V were usually shallower than both $C$. finmarchicus and $M$. longa IV-V. C. armatus IV-V had the deepest day WMDs of the copepods studied, while their night WMDs were similar to $M$. longa. C. finmarchicus adult females had similar WMDs to those of $M$. lucens adult females, remaining shallower than both $M$. longa and $C$. armatus females. C. finmarchicus stages I-III stayed in the surface $50 \mathrm{~m}$ during the whole season. Metridia spp. and $C$. armatus stages I-III had deeper WMDs during the summer months than in winter. $C$. finmarchicus stages IV $-\mathrm{V}$ and adult females all showed a lessening of the day and night WMD in April, followed by a deepening in June/July. This seasonal trend was also seen in $M$. longa and $M$. lucens stage $V$ and adult females, where the WMDs became more shallow in April/May, and deepened again in the late summer.

Chiridius armatus stages IV-VI had almost constant day WMDs for all stages on all dates (Fig. 8). However, a slight reduction in the daytime WMD was observed in April/May. The night WMDs of C. armatus varied during the season, being shallow in February, deepening in April to July, and becoming more shallow again in September/October. Calanus finmarchicus males showed no clear DVM, and were found deeper than adult females in early spring. As the migration amplitude of females increased later in the season, males stayed both day and night at the night WMD of females, which gradually became more shallow during the season. Metridia longa and $M$. lucens adult males

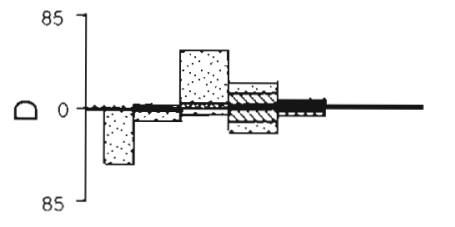

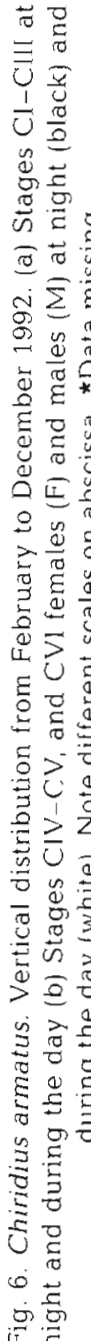

were usually slightly deeper than their females, especially during night. C. armatus males showed similar vertical distribution and migration patterns to those of their females.

\section{DISCUSSION}

The avoidance of visual predators, such as planktivorous fish, is considered to be an important ultimate reason for DVM (Zaret \& Suffern 1976, Gliwicz 1986, Lampert 1989). This predator-evasion hypothesis predicts that zooplankton will be distributed deeper in summer so that they are not exposed to high illumination when the risk of mortality from visual predators will be great. The observed seasonal pattern in Chiridius armatus was consistent with this prediction. While the day WMDs of $C$. armatus were fairly constant throughout the year (200 to $380 \mathrm{~m}$ ), a seasonal trend 
$\geqslant \quad \overrightarrow{0}$
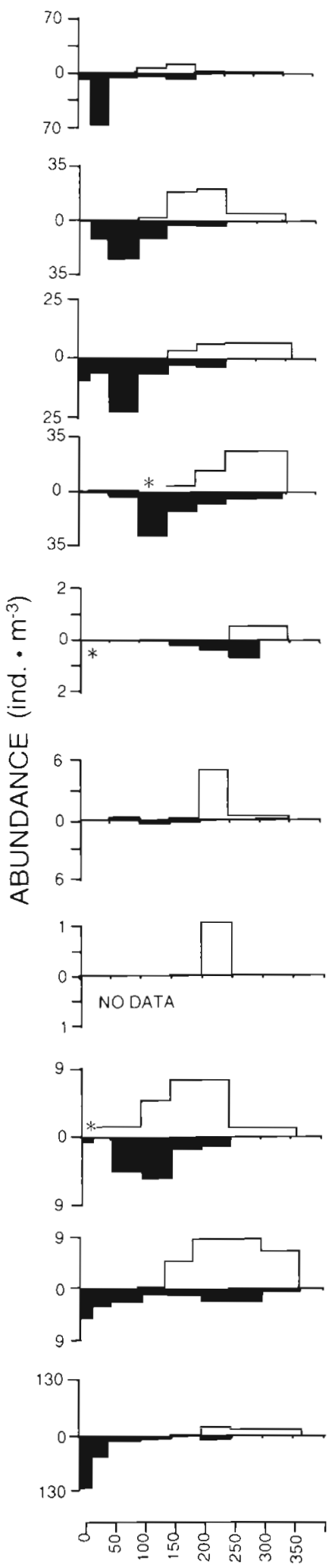

요
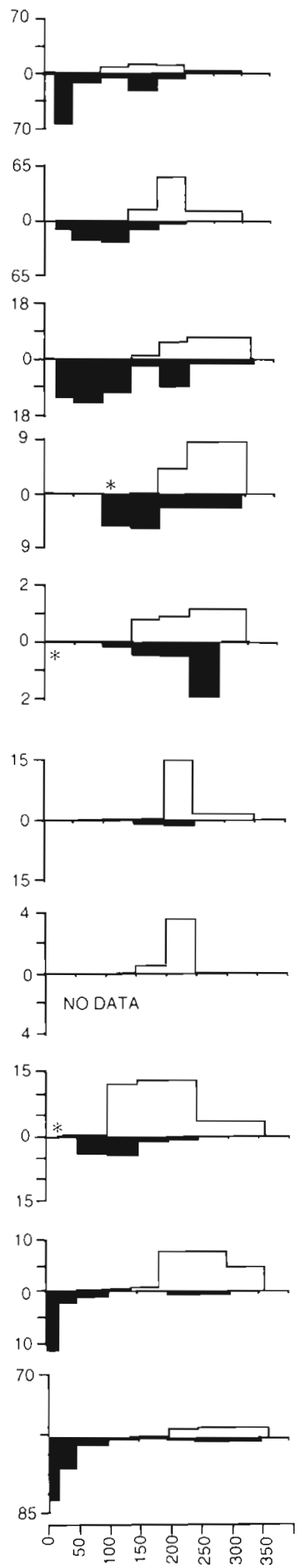

$\operatorname{DEPTH}(\mathrm{m})$ $\amalg$
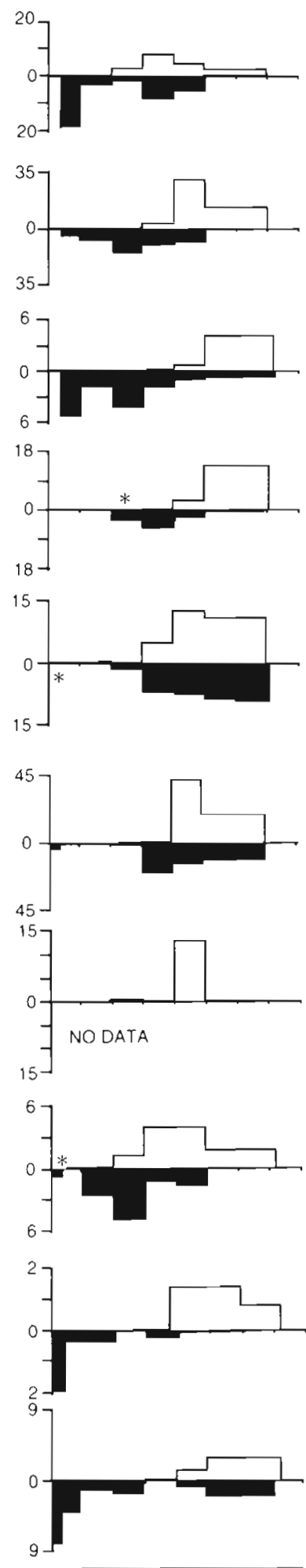

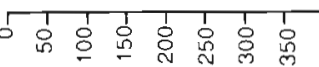
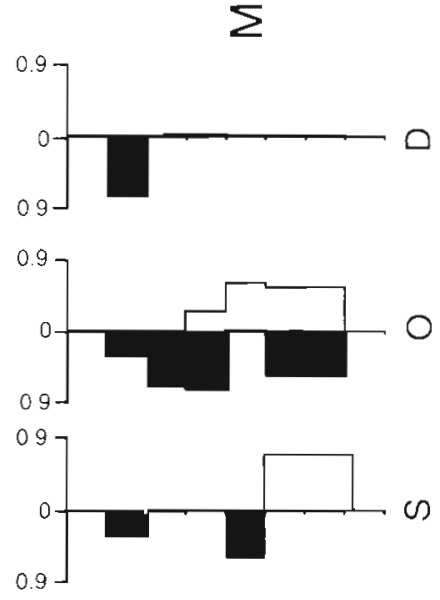

NO MALES OBSERVED $\varangle$
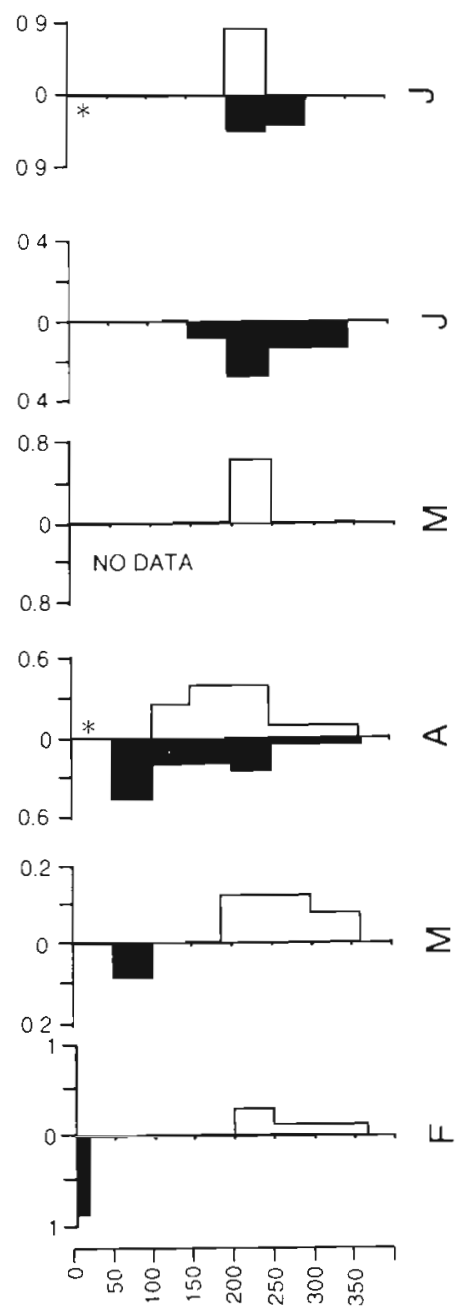
Table 1. Migration strength $(V)$ of all copepodid stages of Calanus finmarchicus, Metridia longa, M. lucens and Chiridius armatus in Malangen, 1992. V is calculated according to Bollens \& Frost (1989): $V=1$ indicates maximum migration strength, while $V=0$ indicates no diel vertical migration

\begin{tabular}{|c|c|c|c|c|c|c|c|c|c|c|}
\hline & $\mathrm{F}$ & M & A & $M$ & J & $\mathrm{J}$ & $A$ & $\mathrm{~S}$ & $\mathrm{O}$ & $\mathrm{D}$ \\
\hline \multicolumn{11}{|c|}{ Calanus finmarchicus } \\
\hline I & - & - & 0.37 & - & 0.00 & -0.02 & -0.04 & 0.50 & - & - \\
\hline II & - & - & 0.16 & - & 0.12 & -0.23 & -0.58 & 0.05 & -0.76 & - \\
\hline III & - & - & 0.15 & - & 0.22 & -0.65 & 0.30 & 0.10 & 0.64 & - \\
\hline IV & 0.03 & -0.08 & 0.16 & - & 0.16 & 0.26 & 0.16 & 0.18 & 0.01 & 0.09 \\
\hline V & 0.18 & 0.28 & 0.37 & - & 0.37 & 0.10 & 0.18 & 0.26 & -0.03 & 0.13 \\
\hline Female & 0.16 & 0.12 & 0.23 & - & 0.44 & -0.11 & 0.33 & 0.50 & 0.44 & 0.23 \\
\hline Male & 0.26 & -0.16 & 0.00 & - & 0.08 & -0.12 & -0.36 & 0.81 & -0.84 & - \\
\hline \multicolumn{11}{|c|}{ Metridia spp. } \\
\hline I & -0.54 & 0.23 & -0.02 & - & 0.14 & -0.03 & -0.19 & -0.29 & -0.29 & -0.35 \\
\hline II & 0.01 & -0.47 & -0.17 & - & 0.17 & 0.35 & 0.53 & -0.58 & 0.20 & 0.48 \\
\hline III & -0.05 & 0.06 & -0.07 & - & 0.37 & 0.35 & -0.05 & -0.30 & -0.05 & 0.13 \\
\hline \multicolumn{11}{|c|}{ M. longa } \\
\hline IV & -1.00 & - & - & - & 0.33 & 0.46 & - & - & - & - \\
\hline V & -0.66 & -0.45 & - & - & 0.36 & 0.51 & 0.28 & 0.62 & -0.11 & 0.53 \\
\hline Female & 0.08 & -0.04 & 0.45 & - & 0.26 & 0.51 & 0.21 & 0.84 & -0.16 & 0.57 \\
\hline Male & -0.03 & -0.12 & -0.27 & - & 0.09 & 0.48 & -0.67 & 0.04 & 0.00 & 0.54 \\
\hline \multicolumn{11}{|c|}{ M. lucens } \\
\hline IV & 0.23 & 0.45 & - & - & -0.34 & -0.32 & -0.24 & 0.13 & 0.39 & 0.21 \\
\hline V & 0.29 & 0.36 & -0.64 & - & 0.21 & 0.43 & 0.52 & 0.41 & 0.29 & 0.42 \\
\hline Female & 0.32 & 0.59 & 0.07 & - & 0.62 & 0.44 & 0.37 & 0.76 & 0.29 & 0.72 \\
\hline Male & 0.14 & -0.08 & -0.11 & - & -0.42 & -0.19 & -0.04 & 0.14 & 0.01 & 0.19 \\
\hline \multicolumn{11}{|c|}{ Chiridius armatus } \\
\hline I & 0.39 & 0.43 & 0.24 & - & 0.00 & -0.17 & 0.31 & 0.54 & 0.33 & 0.05 \\
\hline II & 0.34 & 0.30 & 0.27 & - & 0.22 & -0.14 & 0.30 & 0.62 & 0.38 & 0.61 \\
\hline III & 0.88 & 0.31 & 0.03 & - & 0.33 & 0.22 & 0.53 & 0.69 & 0.62 & 0.63 \\
\hline IV & 0.87 & 0.41 & 0.45 & - & 0.82 & 0.48 & 0.66 & 0.80 & 0.78 & 0.68 \\
\hline V & 0.76 & 0.74 & 0.43 & - & 0.00 & -0.06 & 0.59 & 0.69 & 0.76 & 0.44 \\
\hline Female & 0.58 & 0.77 & 0.48 & - & -0.27 & -0.07 & 0.47 & 0.81 & 0.53 & 0.60 \\
\hline Male & 1.00 & 1.00 & 0.26 & - & -0.04 & -0.34 & 0.24 & 0.83 & 0.57 & 0.88 \\
\hline
\end{tabular}

Depressed DVM in zooplankton in the absence of diel changes in light intensity has previously been observed in Arctic zooplankton (e.g. Bogorov 1946 , Longhurst et al. 1984, Fisher \& Wisbeck 1993, Loose 1993). Thus, changes in predation intensity need not be invoked to explain the major seasonal changes in the timing of DVM behaviour. While these results still support predator evasion as the ultimate cause of DVM, our results suggest that length of night is the proximate cue that causes seasonal changes in DVM of C. armatus in Malangen.

The seasonal variations observed in the vertical distributions of Calanus finmarchicus and Metridia longa were different from Chiridius armatus. C. finmarchicus was found in the shallow surface layers in March to May, and at the bottom of the fjord in the fall and winter Besides, DVM was low and of variable strength on all dates. Bimodal distributions were observed for larger copepodid stages (CIV-CV) both day and night in summer, which has been considered as an indication of asynchronous vertical migration, where the amount of time spent in surface waters is determined

was seen in the night WMDs, which were deeper during the summer (below $100 \mathrm{~m}$ in June to August) than during the winter months (upper $100 \mathrm{~m}$; Fig 8).

Furthermore, the relative change in light intensity is thought to be the most important proximate factor that initiates upward or downward swimming on a diel cycle (Russel 1927, Cushing 1951, Ringelberg 1964, 1991). DVM in zooplankton are thus expected to decrease during periods of small diel changes in light. The observed vertical distributions of Chiridius armatus are consistent with this prediction, since DVM in stage $\mathrm{V}$ and adults was strong in periods of large day/night contrast (spring and fall), but ceased during the period of midnight sun (Fig. 9). Similarly, the length of time Metridia spp. spent near the surface was found to vary seasonally with the length of night (Hays et al. 1995). Calanus finmarchicus did not perform DVMs during the midnight sun period in Malangen. by individual foraging success (Rudjakov 1970, Pearre 1979). However, we suggest that bimodal vertical distributions were due to asynchronous seasonal migration, with one part of the population staying in the surface both day and night, while another part had migrated down to overwintering depths. Similarly, the bimodal distribution of $C$. finmarchicus adult females in the Canadian Arctic in August was interpreted as a post-reproductive situation (Longhurst et al. 1984). Periods of unimodal distributions of CIV and CV were connected with periods of high food abundance (April), wher the majority of the population was concentrated above $150 \mathrm{~m}$ both day and night, and with the overwintering period (August and onward) when the population had migrated down to overwintering depths (150 to $380 \mathrm{~m}$ ). A small proportion of the $C$. finmarchicus population in Malangen was found in the surface layers during the winter (Fig. 4b). This corrob- 
Fig. 7. Weighted mean depth during the day ( 0 ) and night ( ) of Calanus finmarchicus, Metridia spp. and Chiridius armatus stages Cl-ClII in Malangen, 1992

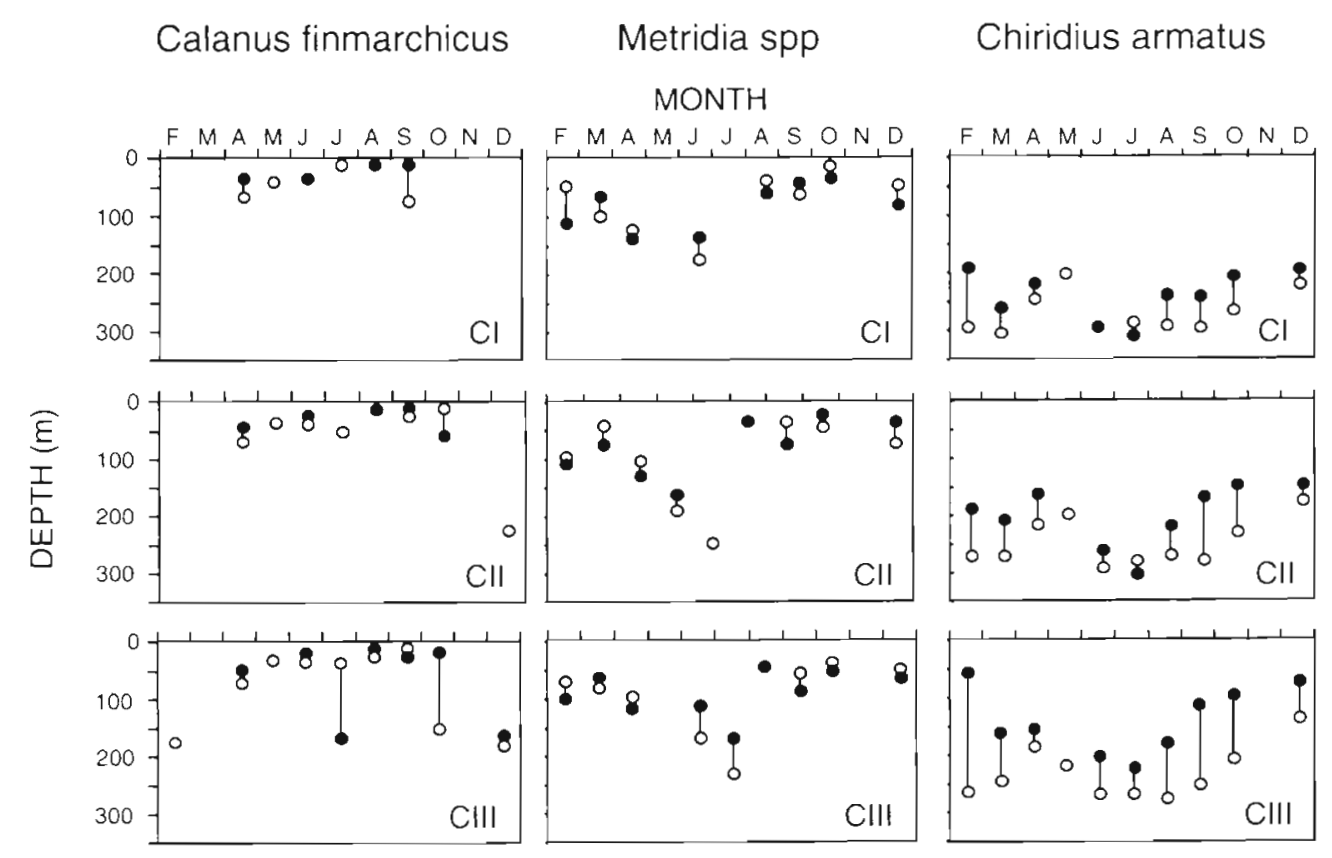

\section{Calanus finmarchicus \\ Metridia spp}

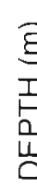

orates findings from other locations in the northern hemisphere (e.g Herman et al. 1981, Bathman et al. 1990, Hirche 1991, Pedersen et al. 1995).

Both Metridia longa and $M$. lucens tended to avoid the surface during the day, with strong indications of
DVM, especially during the summer (Table 1). $M$. lucens showed no clear variations in vertical distribution with season in Malangen, while the daytime depths of $\mathrm{CV}$ and adult $M$. longd were deeper during winter (below $200 \mathrm{~m}$ ) than in the summer $(150$ to $250 \mathrm{~m}$

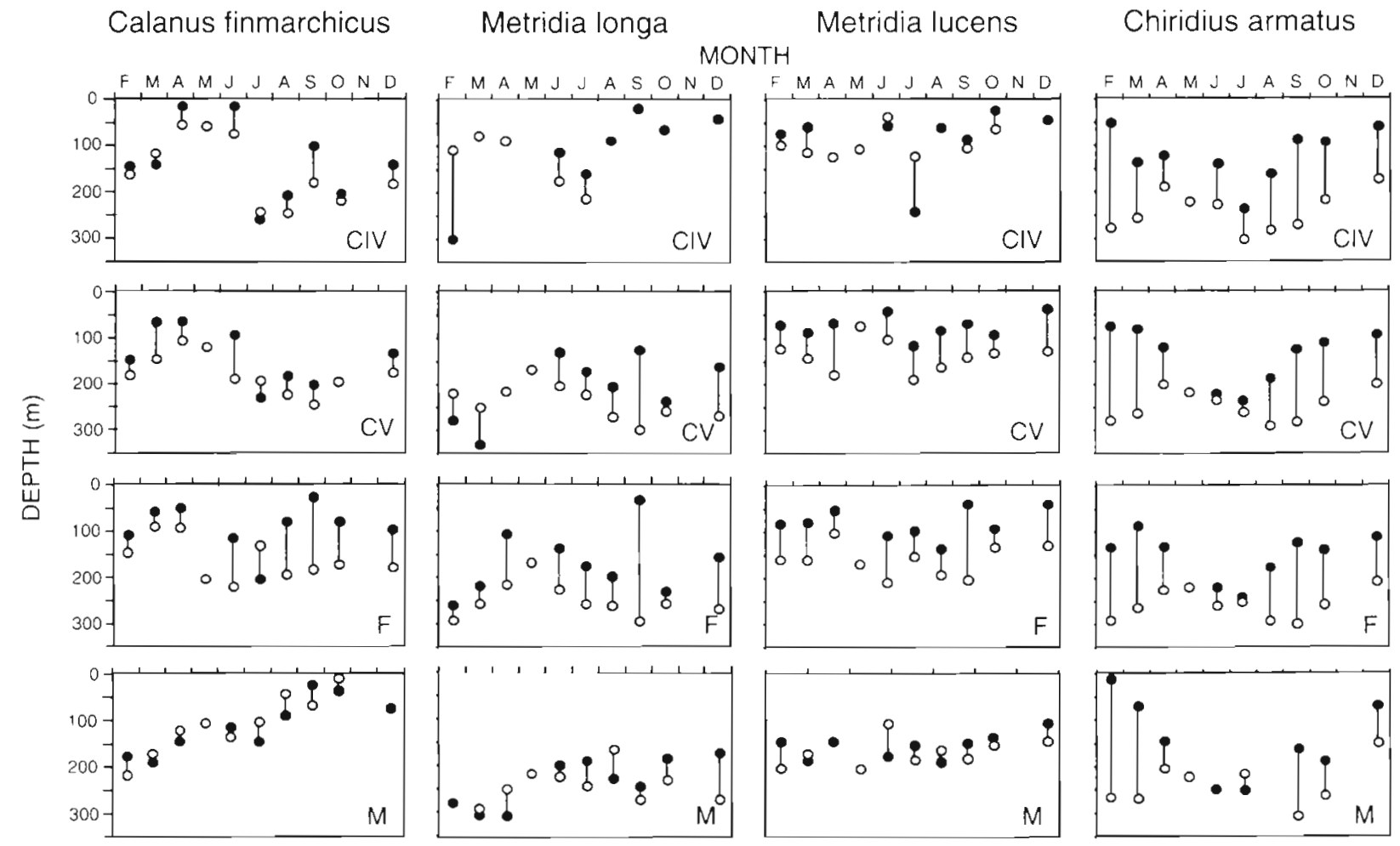

Fig. 8. Weighted mean depth during the day (0) and night ( $)$ of Calanus finmarchicus, Metridia longa, M. lucens and Chiridius armatus stages CIV-CV, and CVI females (F) and males (M) in Malangen, 1992 


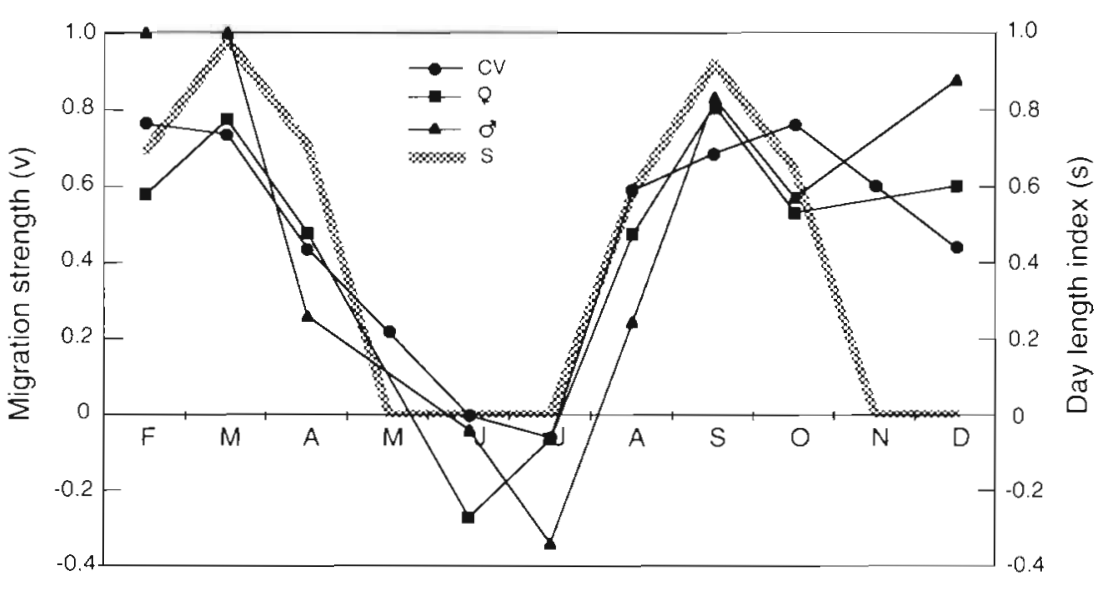

Fig. 9. Migration strength ( $V$ ) of Chiridius armatus stages CIV-CV, and CVI females $(\$)$ and males (o') from February to December 1992. $V$ is calculated according to Bollens \& Frost (1989): $V=1$ indicates maximum migration strength, while $V=0$ indicates no diel vertical migration. Day length index (shaded line) is calculated as $S=$ $1-(D-N \mid 24)$ where $D$ and $N$ are time for sun observed above $(D)$ and below $(N)$ the horizon per day. $S=1$ indicates maximum light variability $(12 \mathrm{~h}$ light and $12 \mathrm{~h}$ dark $\mathrm{d}^{-1}$ ), while $S=0$ indicates minimum variability ( $24 \mathrm{~h}$ light or $24 \mathrm{~h}$ darkness $\mathrm{d}^{-1}$ ) tors. This may cause their own prey to perform reversed DVM, as has been observed in Dabob Bay (Ohman et al. 1983, Frost \& Bollens 1992). Indications of reversed DVM (negative $V$-values in Table 1 ) occurred occasionally in all species studied, but since only a single tow was made at each station, these values could not be tested statistically. However, negative values were most often found in small stages of Metridia spp., which may be most sensitive to these predators (Osgood \& Frost 1994). The zooplanktivorous ctenophore Bolinopsis infundibulum occurred in large quantities during the summer (May to August), but was restricted to the upper $50 \mathrm{~m}$ layer both day and night (Falkenhaug 1996). However, neither $C$. finmarchicus nor Metri- from May to July). In the nearby Balsfjorden, $M$. Ionga (CIV-CV and adults) showed a clear tendency to nocturnal aggregation in the upper layer in September, but occurred within $50 \mathrm{~m}$ of the fjord bottom at noon throughout the year (Bămstedt et al. 1985). Balsfjorden is shallower $(170 \mathrm{~m})$ than Malangen $(380 \mathrm{~m})$, and if these copepods choose their depth according to light conditions, the animals will aggregate close to the bottom during the day in shallow areas.

In addition to light conditions, other variations in environmental conditions may also cause temporal variations in vertical behaviour: salinity gradients of more than 0.2 to $0.3 \%$ per $10 \mathrm{~m}$ have been found to prevent vertical migration of copepods (Banse 1964). Strong gradients in the top $50 \mathrm{~m}$ of Malangen waters from May to August may have contributed to the depression of DVM in Chiridius armatus and Calanus finmarchicus in this period. However, weak migration in these species was also observed in periods with no such physical barriers (Fig. 6b), indicating that other mechanisms are involved. Seasonal changes in predation intensity have previously been found to cause seasonal changes in the vertical behaviour of zooplankton (Ohman et al. 1983, Frost \& Bollens 1992, Bollens et al. 1993). No quantitative data on seasonal variations in fish abundance in Malangen exist, but predation by planktivorous fish is probably highest in summer. Nonvisual predators such as the carnivorous copepod Euchaeta norvegica and the chaetognaths Sagitta elegans and Eukrohnia hamata were regularly found in the fjord, with maximum abundances in February and December (unpubl. data). These predators themselves perform normal DVM in order to avoid visual preda- dia spp. showed any avoidance of the surface layer during this period. C. armatus stayed deep both day and night in summer, thus avoiding predation from both fish and ctenophores.

\section{Inter- and intraspecific differences}

The differences observed among the copepods in this study are consistent with the predator-evasion hypothesis which predicts that those species and developmental stages that are most susceptible to visual predation will spend the least amount of time near the surface. More conspicuous animals (e.g. large, pigmented, or highly active) are better detected by predators and are expected to be stronger migrators (e.g. Zaret 1980 and references therein, Greene 1988, Lampert 1989). We found that both migration amplitude and migration strength increased with the stage of development in all species studied in Malangen. This was most evident in Chiridius armatus where clear differences between day and night distributions were observed in all stages. Similar age-specific differences in DVM behaviour have previously been reported in Calanus finmarchicus (Clarke 1933, Nicholls 1933, Williams \& Conway 1980), C. pacificus (Huntley \& Brooks 1982), C. sinicus (Huang et al. 1992) and Metridia lucens (Osgood \& Frost 1994). However, we found no obvious DVM in small copepodids (CI-CIII) of Metridia spp. and C finmarchicus. Huntley \& Brooks (1982) found small-amplitude $(<1 \mathrm{~m})$ diel migrations in the nauplii and small copepodid stages of C. pacificus. In our study, such small depth differences 
may have gone unnoticed as a result of the larger depth intervals sampled, turbulence, or because of a general lack of synchrony with the light variation and thus a less obvious migration pattern (Pearre 1979).

This study is novel in describing the vertical distribution when the 2 sibling species of Metridia coexist: $M$. lucens were always more shallow than similar stages of $M$. longa, with smaller migration amplitudes. However, older stages of $M$. Iucens ( $C V$ and adult females) performed DVM of more or less constant strength throughout the year ( $V=0.2$ to 0.6 , except from April), whereas similar stages in $M$. longa performed DVM only during the summer (June to September). M. longa and $M$. lucens differ markedly in body size 4.0 and $2.5 \mathrm{~mm}$ prosome length for adult stages respectively; cf. Sars 1903) and hence susceptibility to visual predators should be different. This is consistent with the observed deeper distribution of $M$. Ionga compared to $M$. lucens. However, as observed here and by Osgood \& Frost (1994), similar sized stages of different species have different migration behaviour

Metridia spp. showed a stronger tendency to avoid the surface during the day than did Calanus finmarchicus, and this species was found to perform DVM during the midnight sun period, while C. finmarchicus did not. Metridia has previously been reported to be a stronger migrator than Calanus in other areas (Krause \& Radach 1989, Bollens \& Frost 1992, Osgood \& Frost 1994) and has been found to be more sensitive to light than Calanus (Clarke 1933, Dagg et al. 1989). During the midnight sun period the underwater irradiance does not remain constant during the day, since the solar angle varies. Thus, the observed differences in vertical behaviour may be due to different responsiveness to light among species. Metridia is a more continuously active swimmer than Calanus (Mackas \& Burns 1986, Dagg et al. 1989), and hence susceptibility to predators should be greater. Stuart \& Hugget (1992) found that Euphausia lucens ingested adult $M$. lucens at higher rates than other similar-sized prey. However, Bollens et al. (1993) found a greater electivity of zooplanktivorous fish for $C$. pacificus over $M$. lucens, while Yen (1985) found lower predation rates by Euchaeta elongata on adult $M$. lucens than on similarsized $C$. pacificus. No information on the selective feeding of fish and other predators exists from Malangen

Of the 4 copepod species studied, Chiridius armatus is the most highly pigmented, with a bright red intestine and white, opaque ovarial tubes. This copepod should thus be especially susceptible to visual predators, causing the observed strong DVM related to seasonal variations in light conditions.

The trade-off between feeding and predator avoidance is generally believed to be an important factor in the evolution of vertical behaviour (e.g. Gliwicz 1986, Clark \& Levy 1988). However, the value of food intake relative to reduced predation risk may be different for organisms with different generation times and fecundity (Aksnes \& Giske 1990). As found in this study, younger stages remain at slightly lesser depths than older ones (Fig. 7), since younger stages have higher weight-specific metabolic rates and food requirements (McLaren 1963) and since smaller stages are less susceptible to visual predation (see above). However, in Chiridius armatus, younger copepodid stages were distributed more deeply than older ones (Fig. 8). Larger stages of this species may be more dependent on small copepods as food, which are distributed in the upper layers, whereas young $C$. armatus may avoid the upper layers, with their high risk of visual predation, by feeding on detritus in deeper layers. The vertical behaviour of calanoid copepods is closely linked to their trophic position (Marshall \& Orr 1955). C. finmarchicus is considered to be predominantly herbivorous (see however Ohman \& Runge 1994), with 1 generation $\mathrm{yr}^{-1}$ in these waters (Tande 1982, Tande et al. 1985) This species times its spawning to coincide with periods of high phytoplankton production, and remains near the surface both day and night to feed during the very short period of food abundance. DVM in this species would be costly as a result of reduced access to food. Similarly, daylight feeding in herbivorous copepods has been found during periods of short nights and greater food requirements (Williams \& Lindley 1980, Atkinson et al. 1992). Metridia spp. do not enter the diapause phase (Gronvik \& Hopkins 1984, Batchelder 1985), but become less active during the fall and winter in some areas (Båmstedt et al. 1985, Osgood \& Frost 1994). Species of the genus Metridia certainly eat phytoplankton when it is abundant (Grønvik \& Hopkins 1984, Båmstedt et al. 1985), but consume other food such as microzooplankton during the winter (Haq 1967). C. armatus is classified as an omnivore (Arashkevich 1969, Alvarez \& Matthews 1975), feeding on small copepods, ciliates and possibly detritus (Ottesen 1995). The ability to utilize different types of food makes omnivores less vulnerable to vertical and seasonal variations in phytoplankton, which reduces the cost of DVM.

In conclusion, we suggest that the observed interand intraspecific differences in behaviour are related to life history, diet and conspicuousness. Each of the species studied responded differently to diel and seasonal variations in environmental factors. The vertical distribution of Calanus finmarchicus was thus dominated by seasonal rather than diel migrations, which seemed to be related to the seasonal change in primary production. Metridia spp. were generally consistent diel vertical migrators, $M$. lucens more so than $M$. 
longa. The vertical behaviour of Chiridius armatus was related to the seasonal change in day length, which suggests that light is the main proximate cause of seasonal changes in DVM in this species. For studies made over short time scales these temporal variations may obscure intertaxa differences in the vertical behaviour. Accordingly, these observations emphasize that seasonal studies are needed to fully understand the proximate mechanisms that underlie the vertical behaviour of copepods. Quantification of different predator preferences for different stages and species, along with the distributions and abundances of the predators, would allow more definite conclusions to be drawn on why vertical behaviour varies from species to species and among the different stages of a single species.

Acknowledgements. The authors thank the captain and the crew of RV 'Johan Ruud' and J. T. Eilertsen, K. Lydersen and U. Normann for technical assistance during the cruises. We are grateful to E. Nordby, B. Vaaja, A. Arentsen, U. Zeller, G. Ottesen, G. A. Hansen and S. Jørgensen for their help during sampling and Dr.J. A. Rucijakov, A. Timonin and L. Larsen for assistance with sample identification. Figures were drawn by F. Strand. This work was financially supported by the Norwegian Research Councll through project No. $101703 / 720$.

\section{LITERATURE CITED}

Aksnes DL, Giske J (1990) Habitat profilability in pelagic environments. Mar Ecol Prog Ser 64:209-215

Alvarez V. Matthews JBL (1975) Experimental studies on the deep-water pelagic community of Korsfjorden, western Norway. Feeding and assimilation by Chiridius armatus (Crustacea, Copepoda). Sarsia 58:67-78

Arashkevich YeC (1969) The food and feeding of copepods in the northwestern Pacific. Oceanol Acad Sci USSR 9: $695-709$

Atkinson A, Ward P, Williams R, Poulet SA (1992) Diel vertical migration and feeding of copepods at an oceanic site near South Georgia. Mar Biol 113:583-593

Båmstedt U, Tande KS, Nicolajsen H (1985) Ecological investigations on the zooplankton community of Balsfjorden, northern Norway: physiological adaptions in Metridia longa (Copepoda) to the overwintering period. In: Gray JS, Christiansen ME (eds) Marine biology of polar regions and the effect of stress on marine organisms. John Wiley \& Sons Ltd, Chichester, p 313-327

Banse $\mathrm{K}$ (1964) On the vertical distribution of zooplankton in the sea. Prog Oceanogr 2:53-125

Batchelder HP (1985) Seasonal abundance, vertical distribution, and life history of Metridia pacifica (Copepoda: Calanoida) in the oceanıc subarctic Pacific. Deep Sea Res 32:949-964

Bathman UV, Noji TT, von Bodungen B (1990) Copepod grazing potential in late winter in the Norwegian Sea - a factor in the control of spring phytoplankton growth. Mar Ecol Prog Ser 60:225-233

Bogorov BG (1946) Peculiarities of diurnal vertical migrations of zooplankton in polar seas. J Mar Res 6:26-32

Bollens SM, Frost BW (1989) Predator-induced diel vertical migration in a planktonic copepod. J Plankton Res 11 : $1047-1056$
Bollens SM, Frost BW (1992) Diel vertical migration in zooplankton: field evidence in support of the predator avoidance hypothesis. Hydrobiologia 234:33-39

Bollens SM, Osgood K, Frost B. Watts SD (1993) Vertical distributions and susceptibilities to vertebrate predation of the marine copepods Metridia lucens and Calanus pacificus. Limnol Oceanogr 38:1827-1837

Clark CW, Levy DA (1988) Diel vertical migrations by juvenile sockeye salmon and the antipredation window. Am Nat 131:271-290

Clarke GL (1933) Diurnal migration of plankton in the Gulf of Maine and its correlation with changes in submarine illumination. Biol Bull Woods Hole 65:402-436

Cushing DH (1951) The vertical migration of planktonic crustacea. Biol Rev 26:158-192

Dagg MJ, Frost BW, Walser WE Jr (1989) Copepod diel migration, feeding, and the vertical flux of pheopigments. Limnol Oceanogr 34:1062-1071

Eilertsen HC, Schei B, Taasen JP (1981) Investigations on the plankton community of Balsfjord, northern Norway: the phytoplankton 1976-1978. Abundance, species composition and succession. Sarsia 66:129-141

Falkenhaug $T$ (1996) Distributional and seasonal patterns of ctenophores in Malangen, northern Norway. Mar Ecol Prog Ser 140:59-70

Falkenhaug T, Nordby E, Svendsen H, Tande K (1995) Impact of advective processes on displacement of zooplankton biomass in a north Norwegian fjord system: a comparison between spring and autumn. In: Skjolda] HR, Hopkins C, Enkstad KE, Leinaas HP (eds) Ecology of fjords and coastal waters. Elsevier Science BV, Amsterdam, p $195-217$

Falkenhaug T, Tande KS, Timonin A (1997) Spatio-temporal patterns in the copepod community in Malangen, northern Norway. J Plankton Res 19(4):449-468

Fisher J, Wisbeck M (1993) Seasonal variation of the daily zooplankton migration in the Greenland Sea. Deep Sea Res 40:1547-1557

Frost BW, Bollens SM (1992) Variability of diel vertical migration in the marine planktonic copepod Pseudocalanus newmani in relation to its predators. Can $J$ Fish Aquat Sci 49:1137-1141

Gabriel W, Thomas B (1988) Vertical migration of zooplankton as an evolutionary stable strategy. Am Nat 132 $199-216$

Gerritsen J, Strickler JR (1977) Encounter probabilities and community structure in zooplankton: a mathematical model. J Fish Res Bd Can 34:73-82

Giske J, Aksnes DL, Balıno BM, Kaartvedt S, Lie U, Nordeide JT, Vea Salvanes AG, Wakili SM, Aadnesen A. (1990) Vertical distribution and trophic interactions of zooplankton and fish in Masfjorden. Norway. Sarsia 75:65-81

Gliwicz MZ (1986) Predation and the evolution of vertical migration in zooplankton. Nature 320:746-748

Greene $\mathrm{CH}(1988)$ Foraging tactics and prey-selection patterns of omnivorous and carnivorous copepods. Hydrobiologia 167/168:295-302

Gronvik S, Hopkins CCE (1984) Ecological investigations of the zooplankton community of Balsfjorden, northern Norway: generation cycle, seasonal vertical distribution, and seasonal variations in body weight and carbon and nitrogen content of the copepod Metridia longa (Lubbock) J Exp Mar Biol Ecol 80:93-107

Haq SM (1967) Nutritional physiology of Metridia Lucens and M. longa from the Gulf of Maine. Limnol Oceanogr 12 : $40-51$

Hays GC. Warner AJ, Proctor CA (1995) Spatio-temporal pat- 
terns in the diel vertical migration of the copepod Metridia lucens in the northeast Atlantic derived from the Continuous Plankton Recorder survey. Limnol Oceanogr 40 $469-475$

Herman AW, Sameoto DD, Longhurst AR (1981) Vertical and horizontal distribution patterns of copepods near the shelf break south of Nova Scotia. Can J Fish Aquat Sci 38 $1065-1076$

Hırche HJ (1991) Distribution of dominant calanoid copepod species in the Greenland Sea during late fall. Polar Brol 11. $351-362$

Huang C, Uye S, Onbe T (1992) Ontogeneuc diel vertıcal migration of the planktonic copepod Calanus sinicus in the Inland Sea of Japan. Mar Biol 113:391-400

Huntley M, Brooks ER (1982) Effects of age and food availability on diel vertical migration of Calanus pacificus. Mar Biol 71:23-31

Kerfoot WC (1985) Adaptive value of vertical migration: comments on the predation hypothesis and some alternatives. Contrib Mar Sci Suppl 27:91-113

Krause M, Radach G (1989) On the relations of vertıcal distribution, diurnal migration and nutritional state of herbivorous zooplankton in the northern North Sea during FLEX 1976. Int Rev Ges Hydrobiol 74:371-417

Lampert WH (1989) The adaptive significance of diel vertical migration of zooplankton. Funct Ecol 3:21-27

Landry MR (1978) Population dynamics and production of a planktonic copepod, Acartia clausii, in a small temperate lagoon on San Juan Island, Washington. Int Rev Hydrobiol $63: 77-119$

Longhurst AR, Sameoto DD, Herman AW (1984) Vertical distribution of Arctic zooplankton in summer: eastern Canadian Archipelago. J Plankton Res 6:137-168

Loose CJ (1993) Lack of endogenous rhythmicity in Daphnia diel vertical migratıon. Limnol Oceanogr 38:1837-1841

Mackas D, Burns KE (1986) Poststarvation feedıng and swimming activity in Calanus pacificus and Metridia pacifica. Limnol Oceanogr 31:383-392

Marshall SM, Orr AP (1955) The biology of a marine copepod Calanus fınmarchicus (Gunnerus). Oliver \& Boyd, Edinburgh

McLaren IA (1963) Effects of temperature on growth of zooplankton, and the adaptive value of vertical migration. J Fish Res Bd Can 20:685-727

Motoda S (1959) Devices of simple plankton apparatus. Mem Fac Fish Hokkaido Univ 7:73-94

Mullin MM (1979) Longshore variation in the distrubution of plankton in the Southern California Bight. CalCOFI Rep 20:120-123

Nicholls AG (1933) On the biology of Calanus finmarchicus III. Vertical distribution and diurnal migration in the Clyde Sea area. J Mar Biol Assoc UK 19:139-164

Ohman MD (1990) The demographic benefits of diel vertical migration by zooplankton. Ecol Monogr 60:257-281

Ohman MD, Frost BW, Cohen EB (1983) Reverse diel vertical migration: an escape from invertebrate predators. Science 220:404-407

Ohman MD, Runge JA (1994) Sustained fecundity when phytoplankton resources are in short supply: omnivory by Calanus finmarchicus in the Gulf of St. Lawrence. Limnol Oceanogr 39:21-36

Osgood KE, Frost BW (1994) Ontogenetic diel vertical migration behaviors of the marine planktonic copepods Calanus pacificus and Metridia lucens. Mar Ecol Prog Ser 104: $13-25$

Ottesen GO (1995) Feeding ecology in two carnivorous copepods, Chiridius armatus and Euchaeta norvegica (Boeck), in north Norwegian waters Masters thesis, Norwegian College of Fishery Science, Tromsø (in Norwegian)

Pearre S Jr (1973) Vertical migration and feeding in Sagitta elegans Verrill. Ecology 54:300-314

Pearre S Jr (1979) Problems of detection and interpretation of vertical migration. J Plankton Res 1:29-44

Pedersen G, Tande KS, Ottesen GO (1995) Why does a component of Calanus finmarchicus stay in the surface waters during the overwintering period in high latıtudes? ICES J Mar Sci 52:523-531

Ramcharan CW, Sprules WG (1991) Predator-induced behavioral defense and its ecological consequences for two calanoid copepods. Oecologia 86:276-286

Ringelberg $J$ (1964) The positive phototactic reaction of Daphnia magna Straus: a contribution to the understanding of diurnal vertical migratıon. Neth J Sea Res 2 $319-406$

Ringelberg J (1991) A mechanism of predator-mediated induction of diel vertical migration in Daphnia hyalina. J Plankton Res 13:83-89

Rudjakov JA (1970) The possible causes of diel vertical mıgrations of planktonic animals. Mar Biol 6:98-105

Russel FS (1927) The vertical distribution of plankton in the sed. Biol Rev 2:213-262

Sars GO (1903) An account of the Crustacea of Norway, Copepoda (Calanoida), Vol lII-IV. Bergen Museum

Stuart V, Hugget JA (1992) Prey selection by Euphausia lucens (Hansen) and feeding behavior in response to a mixed algal and animal diet. J Exp Mar Biol Ecol 164: $117-133$

Sullivan BK (1980) In situ feeding behavior of Sagitta elegans and Eukrohnia hamata (Chaetognatha) in relation to the vertical distribution and abundance of prey at Ocean Station ' $\mathrm{P}$ ' L.mnol Oceanogr 25:317-326

Tande KS (1982) Ecological investigations on the zooplankton community of Balsfjorden, northern Norway: generation cycles and variations in body welght and body content of carbon and nitrogen related to overwintering and reproduction in the copepod Calanus finmarchicus (Gunnerus). J Exp Mar Biol Ecol 62:129-142

Tande KS, Hassel A, Slagstad D (1985) Gonad maturation and possible life cycle strategies in Calanus finmarchicus and Calanus glacialis in the northwestern part of the Barents Sea. In: Gray JS, Christiansen ME (eds) Biology of polar regions and effects of stress on marine organisms. John Wiley \& Sons Ltd, Chichester, p 141-155

Wiebe PH, Morton AW, Bradley AM. Backus RH, Craddock JE, Barber V. Cowles TJ, Flierl GR (1985) New developments in the MOCNESS, an apparatus for sampling zooplankton and micronecton. Mar Biol 87:313-323

Williams R, Conway DVP (1980) Vertical distributions of Calanus finmarchicus and C. helgolandicus. Mar Biol 60: $57-61$

Willıms R, Lindley JA (1980) Plankton of the Fladen Ground durng FLEX 76. IIl Vertical distribution, population dynamics and production of Calanus finmarchicus. Mar Biol 60:47-56

Yen J (1985) Selective predation by the carnivorous marine copepod Euchaeta elongata: laboratory measurements of predation rates verified by field observations of temporal and spatial feeding patterns. Limnol Oceanogr 30: $577-597$

Zaret TM (1980) Predation and freshwater communities. Yale University Press, New Haven, CT

Zaret TM, Suffern JS (1976) Vertical migration in zooplankton as a predator avoidance mechanism. Limnol Oceanogr 21 $804-813$ 